\title{
ANALYSIS OF THE USE OF PERSONAL PROTECTIVE EQUIPMENT BY SMALL CONSTRUCTION WORKERS IN THE MUNICIPALITY OF PRESIDENTE FIGUEIREDO
}

\author{
Sinndy Rossaly Cabral de Oliveira ${ }^{1}$, David Barbosa de Alencar ${ }^{2}$, Ana Caroline da Silva \\ Taumaturgo $^{3}$, Ítalo Rodrigo Soares Silva ${ }^{4}$, Igor Felipe Oliveira Bezerra ${ }^{5}$ and Manoel Henrique Reis \\ Nascimento $^{6}$
}

\author{
${ }^{1,3}$ Braulo Cardoso de Mattos Higher Education Institute - FASERRA. Manaus-Amazonas, Brazil. \\ 2, 4, 6 Galileo Institute of Technology and Education of the Amazon - ITEGAM. Manaus-Amazonas, Brazil. \\ ${ }^{5}$ Nilton Lins University. Manaus-Amazonas, Brazil.
}

Email: srossaly@gmail.com, david002870@hotmail.com, caroline.taumaturgo@gmail.com, italo.computation@gmail.com, igor.bezerra@uniniltonlins.edu.br, hreys@itegam.org.br

Received: Aug 29th, 2019

Accepted: Aug 30th, 2019

Published: December 02 ${ }^{\text {th }}, 2019$

Copyright (02016 by authors and Galileo Institute of Technology and Education of the Amazon (ITEGAM).

This work is licensed under the Creative Commons Attribution International License (CC BY 4.0).

https://creativecommons.org/licen ses/by/4.0/

\begin{abstract}
The uses of Individual Protection Equipment is fundamental to guarantee the professional safety, the objective of this work was to analyze how the small construction companies has been handling this subject in Amazonas, specifically in the Municipality of Presidente Figueiredo, where the research was carried out. A questionnaire was applied addressing topics of simple understanding for a better understanding of the interviewees. With the results of the research, comparative charts were elaborated. The research results reveal that employees have knowledge about the use of PPE, but there is a great lack of supervision and management of work safety in the participating companies.
\end{abstract}

Keywords: Personal Protection Equipment, Questionnaire, Professionals.

\section{INTRODUTION}

Work accident is not only the 21ST century, since antiquity is already heard in accidents and diseases caused by lack of good working conditions, the theme gained more repercussion after the industrial reform, because it was when it was observed the need for Require better conditions and study a way to prevent the occurrence of occupational accidents and illnesses. It is important to mention that accidents and occupational diseases have a socioenvironmental, economic and political reflex for the whole of society and for the countries [1].

Even though it is a topic discussed for many years, it still needs more attention and study focused on prevention and care, there are some steps that should be considered for further investigation in situations with greater potential for danger, example This is a greater perception in industrial equipment, in the planning of actions and even in the training and information of workers regarding the tasks that will be entrusted to them and the technical means to accomplish them [2].
A fundamental strategy in the prevention action is the use of personal protective equipment. The famous EPIs, can minimize the risks and even prevent accidents from taking larger proportions. But the secret is the supervision and training of how to use and use the equipment properly. This item is seen as some irrelevant to small and medium sized companies, because some of them believe that only the fact of delivering the PPE is enough, they do only for table fulfillment, without the real concern of raising awareness and keeping their Employees.

This research has as main objective to understand how the safety of work is applied in municipalities of Amazonas, places where the surveillance is less active and for this will be applied a questionnaire about the use of Ppe and cases of occupational accidents and Later, comparative charts and interpretations are presented. Finally, the author's conclusion on the topic approached. 


\section{LITERATURE REVISION}

To better understand the subject to be addressed, it is necessary to deepen the themes related to the content of the research, thus clarifying any doubts about the topic approached.

\section{II.1 HYGIENE AND OCCUPATIONAL SAFETY}

For [3] occupational safety can be understood as the Union of linked methodologies to minimize work accidents, with the main objective being the identification of risks in the work environment.

Already for [4] The safety of work is the study of the possible chances of accident in the workplace, and its greatest commitment is prevention, as many accidents as occupational diseases.

Occupational safety is nothing more than the Union of Science and technology, with the aim of preventing and protecting employees in their workplace, seeking to reduce and avoid occupational accidents.

\section{II.1.1 HISTORY OF HYGIENE AND OCCUPATIONAL SAFETY}

The concern with the safety of work is not recent, in Deuteronomy, Chapter 8, verse 22, says: “(...) When you build a new house, you'll make a balustrade around the ceiling, so you don't spill blood on your house, if someone came to fall from above".

In the years 1700. The physician Bernadino Ramazzini, published a book called "Morbis Artificum Diatriba (occupational diseases)", this book gained repercussions for describing several diseases caused by the professions of the time, becoming known as the "Father" of Medicine of the Work.

\section{II.1.2 THE HISTORY OF OCCUPATIONAL SAFETY IN THE INDUSTRIAL REVOLUTION}

The Industrial Revolution burst in England around 1760 and 1830 , with this brought great advancement, the emergence of powerful machines of spinning and weaving caused great technological impressions and also the substitution of man by the machine, but if we stopped to Analyze, the whole picture took on serious situations, the worker had no human respect, all worked, men, women and children, employers did not give any work conditions, much less security and accidents were common, In this period of inactivity, the worker did not receive a salary and there were no laws that would stop him. Not only did accidents happen, but also typical illnesses or worsened by the professional environment [5].

The workers tired of the poor working conditions, began to organize in unions in an attempt to claim better conditions, thus emerging the first movements against the terrible working conditions and unhealthy environments.

\section{II.1.3 THE HISTORY OF OCCUPATIONAL SAFETY IN THE PRESENT DAY}

With the passing of time, the creation of trade unions and the evolution of the market the safety of work was undergoing relevant changes. More developed countries were giving more importance to life, and thus was emerging better conditions in the working environments [6].

The first laws emerged in Brazil in 1919, but only in 1972 that the history of occupational safety has changed considerably, with the emergence of Ordinance No. 3,237, where it was established the mandatory services specialized in safety, hygiene and Work medicine in companies.

Many other ordinances were created from this, but the most important and outstanding current: The one of June 8, 1978, of No. 3,214 , because the regulatory norms, NR's, of chapter V of the CLT were approved. Currently we have 37 active regulatory standards, much still needs to be done and supervised to, thus obtaining better results in relation to the safety of the worker in our country, because the accidents still happen alarmingly!

\section{II.2 PERSONAL PROTECTIVE EQUIPMENT}

The personal protective equipment-PPE is of paramount importance to ensure the protection and health of the employee, decreasing the risk in cases of accidents at work, because used correctly ensured that the professional does not be exposed to occupational illnesses, which Can compromise your entire life [7].

When it comes to safety and health at Work (OSH), the priority is to map any and all potentially dangerous risks, which put the life and health of the employee at risk, and eliminate at the origin, but not all risks can be premeditated and therefore the use of PPE is essential [8].

\section{II.3 CONSTRUCTION SUPERVISION}

The supervision of the use of PPE is the responsibility of the company, but not only of it because there is law and bodies responsible for inspecting companies as to the length of the law and ensuring that each company fulfils its role to safeguard and protect the health of its Employees

Thus, it is important to emphasize that the objective responsibility comes from a lawful act and that it is independent of the existence of guilt, that is, it will be necessary to prove the existence of the damage and the causal link, as the art. 927, single paragraph of the Civil code, in the following terms: ART. 927. He who, by illicit act (arts. 186 and 187), deals damage to others, is obliged to repair it. Single paragraph. There will be an obligation to repair the damage, regardless of guilt, in the cases specified in law, or when the activity normally developed by the offender implies, by its nature, risk to the rights of others.

The law is clear in stating that at the time the company causes some damage to the employee, has a duty to repair it, ie the employer has obligation to care and accompany if the employee is using the EPIs that keeps his safe every day and this comes through the tax To have in the workplace a technical responsible to supervise and study ways to reduce any risk is of paramount importance to the development of the company, because a safe environment generates a productive and healthy environment [9].

\section{II.4 WORK IN HEIGHT AND NR 35}

Among the most common accidents in civil construction, this related to falls, and cause most of the time is due to lack of adequate safety equipment and lack of training for workers who perform services at height [10]. 
The NR 35 [11] is a norm for the management of safety and health at work at height, aims to establish conditions for the protection of employees to the risks of falling, each situation or better each level, has aspects of prevention. Depending on the complexity of the risk, the employer must adopt measures

Complementary inherent to these activities, there is a universe of control measures and preventive systems, possible of application, and that, consequently, there is much more to be studied, planned and implemented [12].

All work at height had to be planned and studied, in order to reduce the possible risks that the collaborator will be subjected to, this analysis done with antecedance, seeks to minimize the risks of falling and plan calmly or even reduce its Consequences, the risk of falling with differences in levels cannot be avoided. By using the methodology of risk analysis, some measures can be taken with preconditions and the regulatory norms may note the elaboration of these measures [12].

\section{II.4.1 NBR 6494 - SAFETY STANDARD IN SCAFFOLDING}

According to [13] NBR 6494, in item 2.1, scaffolding is defined as: "Platforms necessary for the execution of jobs in high places, where they cannot be executed under safety conditions from the floor." They are widely used.

In amusement services of renovation, painting, construction, cleaning, maintenance and demolition. Its production is common with metal tubes of pre-established sections with diagonal latuses that form gantry structures with possibility of multiple regulation. For each type of service the standard standardizes a specific type of scaffold.

\section{MATERIAL AND METHODS}

The research was conducted in the municipality of Presidente Figueiredo, interior of Amazonas, $107 \mathrm{~km}$ away from the capital, with 2 different engineering companies that are working in the municipality, small companies, with variations of 25 employees per bed, This study was divided into 3 stages, the first being a bibliographical survey, for a better understanding of the subject to be analyzed, the second, a field research, hearing and experiencing the reality of the collaborators in the day-to-day and the third was the conclusion of Comparison of the data obtained.

We will not cite the names of companies, so as not to have any discomfort, but (no need to justify the quotation of companiescan delete) they have something in common, both are performing services in the heights, with the aid of scaffolding, example of source Potential accidents.

With the variation in the number of employees of the companies, it was pre-defined that it would be interviewed 15 employees of each company, being a random choice and voluntarily, the questions were elaborated in analyzing the previous visits, as to the Questioning the non-use of PPE personal protective equipment, all questions had theoretical foundations, the questionnaire counted on questions as shown in Figure 01.

The questionnaire was carried out during the working day, being performed individually, without the presence of the employer, to not compromise the results of the research, the collaborators were informed that the information is of academic use and that their answers did not Be disclosed, to ensure the identity of the volunteers and thus obtain the maximum utilization.

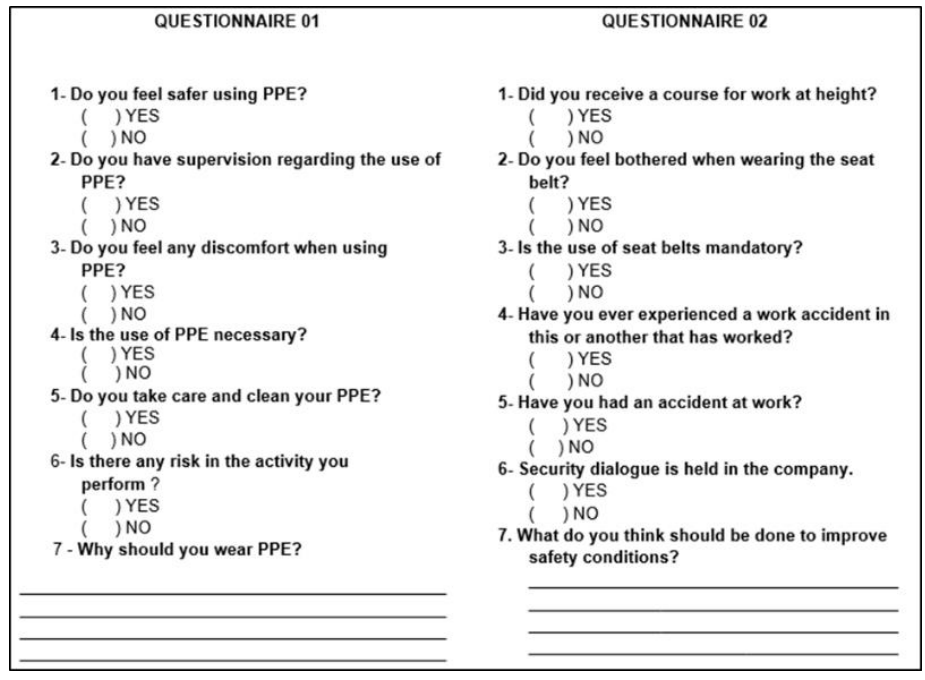

Figure 1: Questionnaire, applied to collaborators for data collection.

Source: Authors, (2019).

\section{RESULTS AND DISCUSSION}

With the results obtained it was possible to create a database, the same were analyzed, counted and posted in a spreadsheet in Excel, being generated comparative charts, the employees were evaluated in their functions, as there was a diversity of Activities enriched the research and obtained more accurate results, due to the variation of the activities.

The questionnaire was divided into two stages, in the first, questions of basic PPE, used in all and any services and the second with questions but specific about the use of safety and PPE in height services with the use of scaffolds, because During the onsite visit, it was observed that both builders used scaffolds in their daily services, with expressive heights, as shown in Figure 2 and 3.

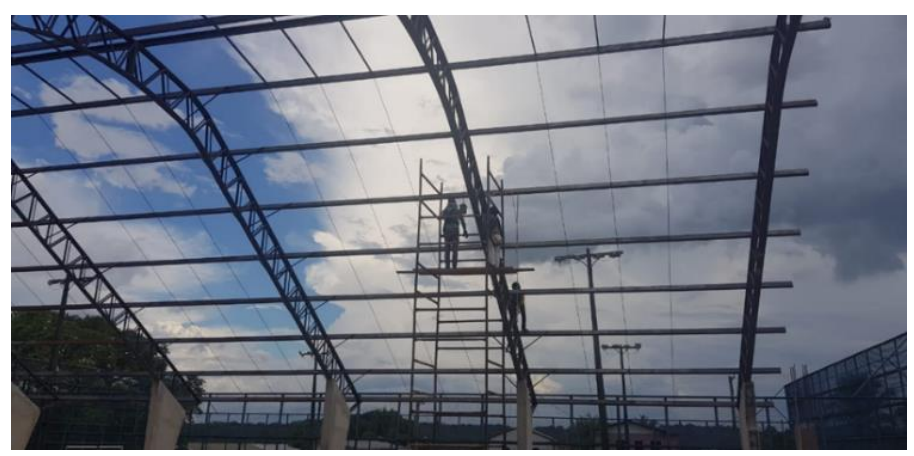

Figure 2: Services in height, with scaffolding. Source: Authors, (2019).

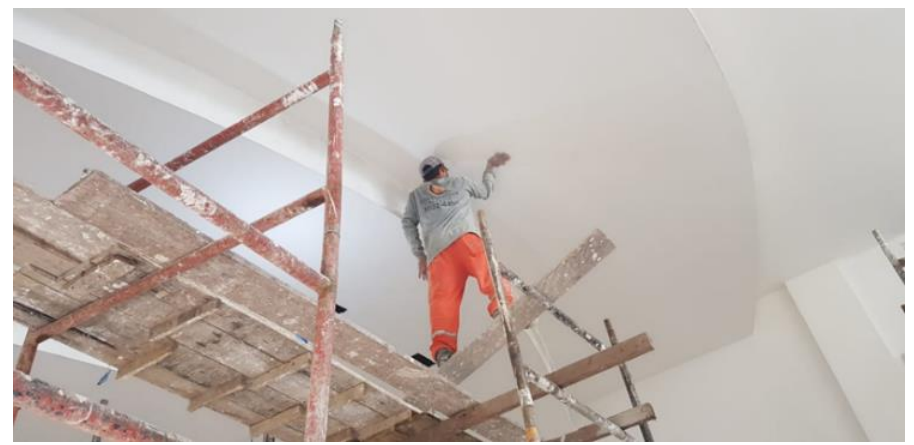

Figure 3: Services in height, with scaffolding and without the use of seat belts.

Source: Authors, (2019). 
For some builders the use of safety equipment is necessary only when it will have supervision, it was detected that it was common to perform such services without the PPE, S, as we can see in Figure 3, the collaborator is without belt Safety, no helmet, no mask and no goggles. The tables that are on the scaffolds are placed improvised, putting the life of the collaborator at risk.

\section{IV.1 PERSONAL PROTECTIVE EQUIPMENT}

The questions that encompass this first stage, were about the basic PPE, the comparative charts bring us clearly the data obtained.

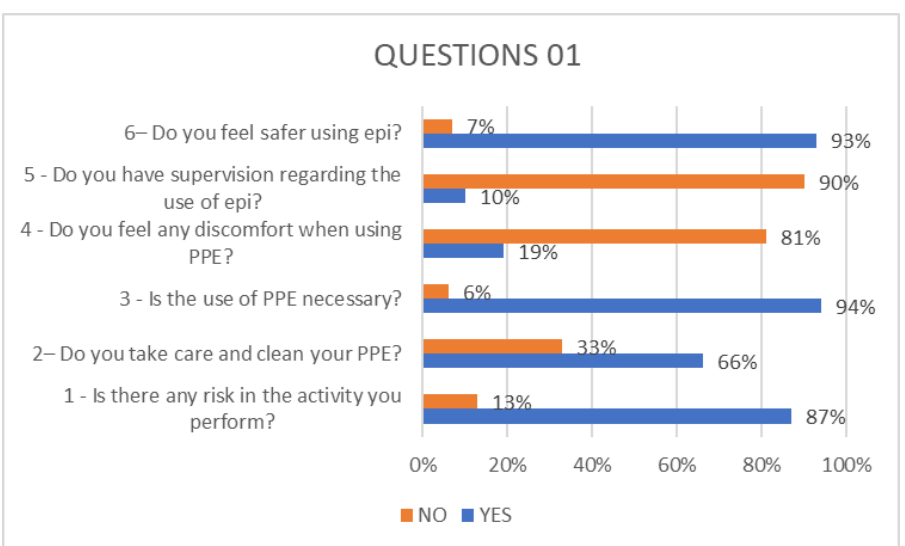

Figure 4: Graph, result of the 1st part of the questionnaire. Source: Authors, (2019).

According to the graph, the first question asked if the collaborators felt safer when using PPE, we obtained $93 \%$ of affirmation, already the $7 \%$ reported that they used only by obligation, in the second question we asked whether there was Supervision regarding the use of PPE, 90\% said they did not have a monitoring that accompanies, causing a certain relaxation in the use of EPIs, in the third question we asked if the use of safety equipment caused some discomfort, and $19 \%$ stated that they did not Like to use PPE, because it warms, bothers, and hinders the realization of activities, already in the fourth question we emphasize the importance of using PPE, s and 94\% affirmed to be aware of the importance of using PPE, S, in the fifth question we ask On hygiene and $66 \%$ affirmed to care and sanitize equipment, in the last question of the first part we seek to understand if they were conscious if the activity they exercised was generating risk for their health and safety, and $87 \%$ of respondents Affirmed that they are conscious, but need the work and perform the activities without proper care and PPE, S.

\section{IV.2 GUIDELINES FOR THE REALIZATION OF THE ACTIVITY}

It is not enough just to deliver the Ppe, it is necessary to orient, promote courses and supervise this use, but as the graph is low, small companies are not paying much attention to this issue.

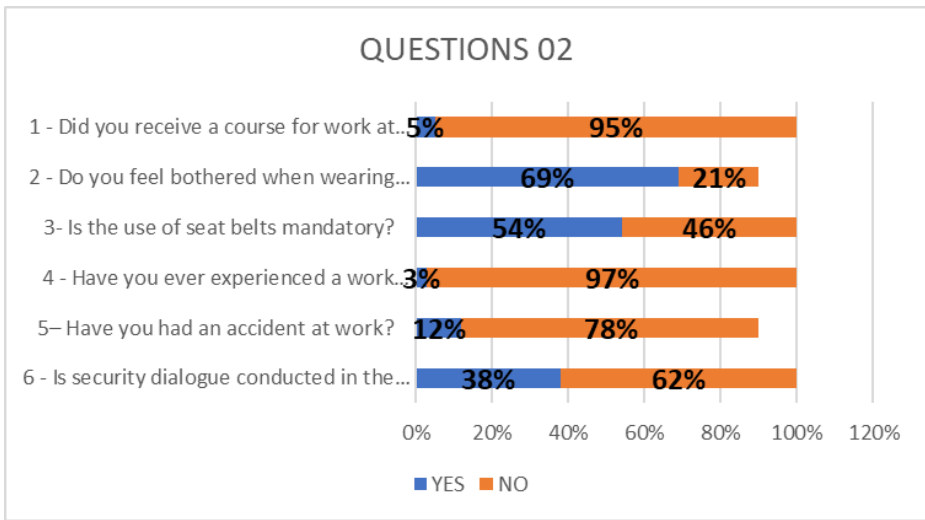

Figure 5: Graph, result of the 2nd part of the questionnaire. Source: Authors, (2019).

Some activities are carried out in height, and according to employees ' statement $95 \%$ never received a course for work at height, the use of the seat belt is 54\% mandatory, but without any guidance. It is important to mention that only $3 \%$ has suffered work accident, accidents that were not recorded because they did not have a greater severity.

\section{IV.3 OPINION OF THE INTERVIEWEE}

The part where employees should transcribe their opinion was of great relevance because they were asked what in their opinion should be done to improve security conditions. As a final answer we obtained that it is necessary to signal with information boards about the risks they run, to make them aware, through lectures showing the consequences of the non-use and the benefits of use, in a more colloquial language and with the use of Pictures. It was also identified that the employees want EPIs of better quality and incredible that it seems they cited the importance of surveillance.

\section{CONCLUSIONS}

After the application of the questionnaires in the companies, it was observed that many collaborators claimed to know the risks that were exposed, but in fact, were unaware of all the risks, for example, during the research it was observed that some of them that Worked directly in the concrete mixer inhaling the "powder" of the cement, and did not use a mask for protection, at the risk of future health problems, another item observed is that they work at heights of 8 to $10 \mathrm{~m}$ and wore the belt only of embellishment, because the same was not fixed in anything that ensured its safety in the event of an accident, still at that point the scaffolds are under bricks at risk of bursting and causing the accident, as shown in the picture 6.

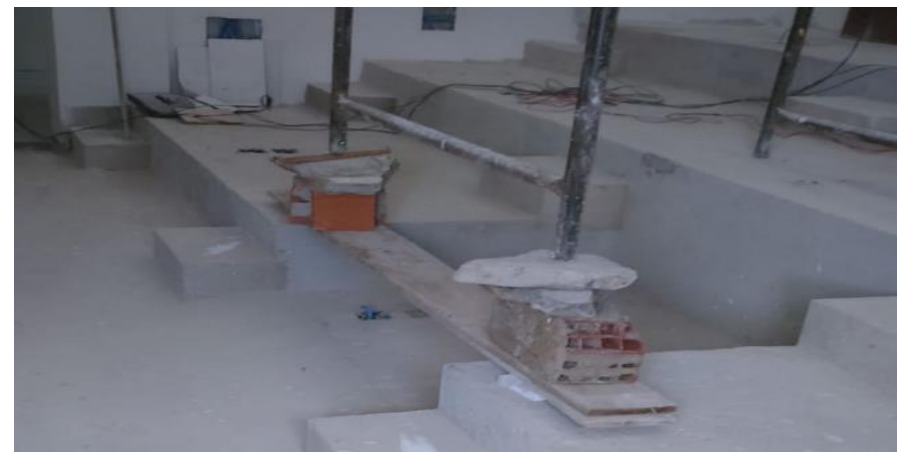

Figure 6: Demonstration.

Source: Authors, (2019). 
We can conclude that the research accomplished succeeded in its goal that was to show how the small and medias companies of the interior of the Amazonas were dealing with work safety theme. There is a major flaw in the organization of the management of occupational safety in companies, especially in small companies where occupational safety is left aside and often being the responsibility of the human resources sector. It is not up to the companies to accuse employees of not using the necessary equipment, if it is the principal responsible for security does not give necessary conditions.

It is also noteworthy that they will have an expressive result if there was a union of the employer with the employee, because a good conversation, listening to the employees and together adapt the situations, would have a minimization of risks.

The responsibility for the health and safety of the work, is not exclusive to one person and nobody talks that alone will have such a result, in this field the Union and the involvement of all is of paramount importance to the prevention of the team.

\section{REFERENCES}

[1] Mattos, Ubirajara; Másculo, Francisco. Higiene e segurança do trabalho. Elsevier Brasil, 2019.

[2] Maia, Leonardo Rocha; Rodrigues, Luciano Brito. Saúde e segurança no ambiente rural: uma análise das condições de trabalho em um setor de ordenha. Ciência Rural, 2012, 42.6: 1134-1139.

[3] De Lima, Valquíria. Ginástica laboral: atividade física no ambiente de trabalho. Phorte Editora, 2018.

[4] Barsano, Paulo Roberto; Barbosa, Rildo Pereira. Segurança do Trabalho Guia Prático e Didático. Editora Saraiva, 2018.

[5] Stülp, Kerley, et al. Determinação, avaliação e medidas de proteção de acidentes no trabalho em altura seguindo as recomendações da NR 35. Revista dos Cursos de Arquitetura e Urbanismo, Engenharia Civil e Engenharia de Produção, 2017, 2.1: 134-151.

[6] Wünsch, Dolores Sanches. Elementos para uma nova cultura em segurança e saúde no trabalho. RBSO, 2007, 32.115: 153-163.

[7] De Azevedo Guimarães, Eliete Albano, et al. Percepção de técnicos de enfermagem sobre o uso de equipamentos de proteção individual em um serviço de urgência. Ciencia y Enfermería, 2011, 17.3: 113-123.

[8] Neves, Heliny Carneiro Cunha, et al. Segurança dos trabalhadores de enfermagem e fatores determinantes para adesão aos equipamentos de proteção individual. Rev Latino-Am. Enfermagem, 2011, 19.2: 354-361.

[9] Veiga, Marcelo Motta, et al. A contaminação por agrotóxicos e os Equipamentos de Proteção Individual (EPIs). Revista Brasileira de Saúde Ocupacional, 2007, 32.116: 57-68.

[10] Ayres, Dennis de Oliveira; Corrêa, José Aldo Peixoto. Manual de prevenção de acidentes do trabalho: aspectos técnicos e legais. São Paulo: Atlas, 2001.
[11] Norma Regulamentadora No 35 - NR35. Trabalho em Altura.

[12] Ministério do Trabalho E Emprego, Normas Regulamentadoras de Segurança e Saúde no Trabalho. Segurança e Saúde no Trabalho, 2019.

[13] Associação Brasileira de Normas Técnicas. NBR 6494: segurança nos andaimes. Rio de Janeiro, 1990. 